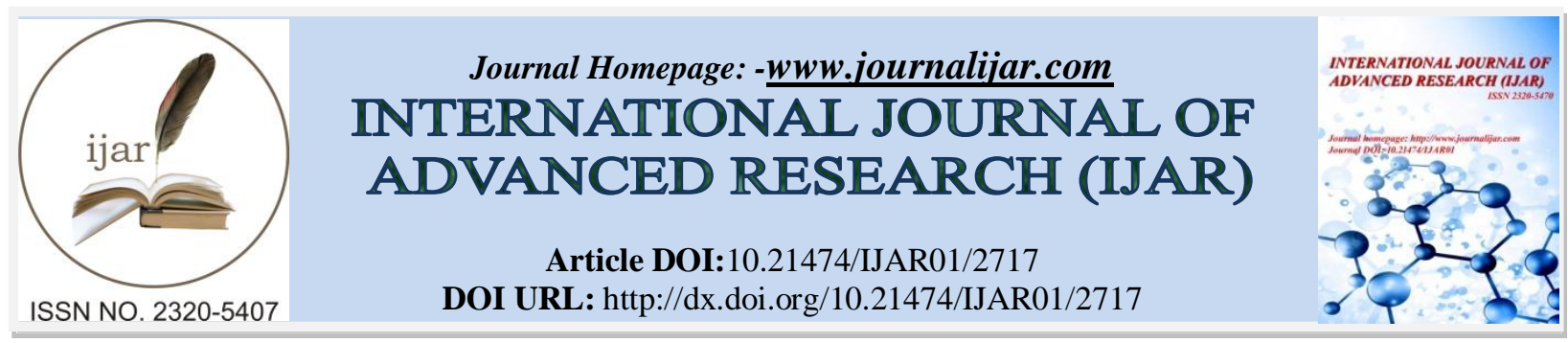

RESEARCH ARTICLE

\title{
FAMILY ENTREPRENEURIAL BUSINESSES AND NEW VENTURES: FORMATION, CHALLENGES, BEHAVIOR, RELATIONSHIP.
}

Mohsen Babaei, Reza Abedi and Masoud Safizadeh

Master of science in Entrepreneurship, Tehran University, Iran

\section{Manuscript Info}

Manuscript History

Received: 15 November 2016

Final Accepted: 17 December 2016

Published: January 2017

Key words: -

Family, Family entrepreneurial

businesses, entrepreneurial teams, new

venture

\section{Abstract}

New ventures are frequently started by entrepreneurial teams rather than lone entrepreneurs. Often, team members have family ties. In this research to study the formation and membership of the team, team challenges, behavior and performance of the team, successors of business and family relationships between members of the team. Combined, they suggest that relationships are more important than skill diversity in determining the effectiveness of both family business and new venture teams

Copy Right, IJAR, 2017, All rights reserved.

\section{Introduction: -}

Despite the popular legend of the heroic lone entrepreneur, the creation and management of new ventures is often a shared, team effort (Kamm et al., 1990; Gartner et al.,1994; West, 2007). Confronted with the simultaneous challenges of creating a firm that is unique and learning to manage in an unknown arena, new venture teams face whatStinchcombe (1965) describes as the liabilities of newness, which involve the difficulties of establishing market legitimacy in the face of time and financial pressures for survival. The distinctive nature and magnitude of the problems facing new ventures suggest they must be managed differently than established firms (Baron, 2002; Ensley, Pearson, \&Amason, 2002; Schjoedt\& Shaver, 2007) and that team involvement is often necessary for success. Thus, the formation, composition, and functioning of entrepreneurial teams can have a profound influence on the survival and growth of a firm. Furthermore, as such teams influence the founding conditions, behaviors, and practices that define the new venture, their initial decisions are likely to leave an enduring imprint on the venture's subsequent development (Beckman \& Burton, 2008). The same can be said for teams in a family business setting. Such teams face unique challenges as well, because overlaid upon all of the problems normally facing entrepreneurial and/or management teams in nonfamily firms are the family relationships among team members that add materially to the complexity of the decisions made about the business (Mitchell, Morse, \& Sharma,2003).

Organizational teams have been studied extensively in the management literature (Mathieu, Maynard, Rapp, \& Gilson, 2008; Stewart, 2010), and important work on teams in the unique contexts of family firms and new ventures has been done. Such work of the latter type has dealt with top management teams and behavioral dynamics (e.g., Ensley \&Pearson, 2005; Ensley et al., 2002; West, 2007), team composition (Knockaert, Ucbasaran,Wright, \&Clarysse, 2011; Ucbasaran et al., 2003; Zimmerman, 2008), compensation(Ensley, Pearson, \&Sardeshmukh, 2007; Monsen, Patzelt, \& Saxton, 2010), and performance(Beckman, Burton, \& O’Reilly, 2007; Francis \& Sandberg, 2000; Hmieleski\&Ensley, 2007; Schjoedt\& Kraus, 2009). However, there is still much we do not know, and there has been a lack of concerted effort to develop a theory that applies to the specific circumstances and contingencies facing entrepreneurial or family business teams. A notable exception is Harper's (2008) work, but his preliminary 
theory of entrepreneurial teams takes an economic rather than a behavioral perspective, which is the focus of this special issue.

The development and application of a behavioral theory of entrepreneurial teams is dependent upon, among other things, a clear definition, common language, and system of classification. Some scholars use ad hoc definitions, while others neglect to define the concept at all (Birley\&Stockley, 2000). Indeed, the term "team" has multiple meanings in the academic and popular press (cf. Hambrick, 1994, and Hambrick, 2007), and the proliferation of terminology is evident by the references to new venture teams, family entrepreneurial teams, core teams, top management teams, and, entrepreneurial teams found in the literature and even this special issue.

Extant definitions of groups and teams have similarities but also meaningful differences (Mathieu et al., 2008). For example, Katzenbach and Smith (1993), Kamm andNurick (1993), Cooper and Daily (1997), Cohen and Bailey (1997), and Cooney (2005) generally agree that while both teams and groups involve a relatively small number of people, teams are composed of members with identifiable features that set them apart such as interdependent skill sets, common goals, shared commitment, and mutual accountability. Unfortunately, if we defined and identified entrepreneurial or family business teams based on all of these characteristics, we would not have many teams to study. Aside from the criterion of small numbers, there are few characteristics common to all such teams. Teams can, and often do, differ in terms of the relationships, functional heterogeneity, and demographic diversity of their members (Mathieu et al., 2008).

Indeed, given the diversity of entrepreneurial or family firm teams and the numerous problems they deal with, we suggest that any definition that goes beyond the number of members and their common but possibly unequal concern for a small set of superordinate goals, which are themselves subject to negotiation, is really seeking to distinguish effective teams rather than teams. Although superordinate goals pertaining to the survival, growth, and ultimate success of a venture or family firm are held more or less in common by team members, the likelihood of differences in both individual and proximal goals for the organization is very large (e.g., Cyert\& March, 1963). Differences in goals also imply differences in preferred strategies and variations in the extent of shared commitment. Furthermore, relationship conflicts can also develop both because of differences in goals and strategies and because of the diverse backgrounds, experiences, and personalities of team members that underlie the differences in their goals. Similarly, information asymmetries and the unobservability of intentions and certain behaviors suggest that mutual accountability will not preclude opportunism, even in family firms (Schulze, Lubatkin, Dino, \&Buchholtz, 2001).

Therefore, teams, whether of the new venture or family firm variety, are really groups of individuals who attempt to work together to achieve a set of imperfectly overlapping and negotiated superordinate organizational goals, potentially for different reasons and often in spite of conflicts emerging from their backgrounds, personalities, and individual motives. In this respect, new ventures and family firms are two contexts in which teams function, and both contexts lead to a unique set of challenges owing to the nature of the problem, the composition of the team, and the behavioral dynamics that influence the process and content of team decisions. Interestingly, the articles in this special issue suggest that while the challenges may vary, the primary ingredient in effective team functioning, the relationships among team members, is consistent across different types of teams. Thus, it appears plausible that a behavioral theory of management teams for new ventures and family firms may be built on a common foundation. With this in mind, we now turn to the research in this special issue.

As argued by Ling and Kellermanns (2010: 323), the family firm indeed offers "a rich avenue for research on diversity, since the family provides an additional layer of complexity and unique sources of TMT ${ }^{1}$ diversity not found in non-family firms." Yet, although the world economy is dominated by this form of organization (La Porta, Lopez-de-Silanes\& Shleifer, 1999) and $\mathrm{EO}^{2}$ is recognized to be a determinant of family firm resilience and long-term survival (Chrisman, Chua \&Steier, 2011; Sharma \&Salvato, 2011), only a few studies have empirically explored the effects of TMT diversity on family firms' EO. Indeed, most of the family business literature focused on the effects of TMT diversity on behavioral dynamics (e.g. Ensley \& Pearson, 2005) and financial performance (e.g. Ling \&Kellermanns, 2010) rather than EO. In addition, most of the family business scholars considered the horizontal distance among family members (e.g. Ensley \& Pearson, 2005) and between family and non-family members (Naldi, Nordqvist, Sjöberg\&Wiklund, 2007; Cruz \&Nordqvist, 2012) as major source of TMT diversity.

\footnotetext{
${ }^{1}$ Top management team

${ }^{2}$ Entrepreneurship orientation
} 
Following Ling and Kellermanns (2010), we focus on the vertical distance among family members as source of TMT diversity: Generational involvement, i.e. the number of family generations simultaneously involved in the firm TMT (Kellermanns\&Eddleston, 2006; Ling \&Kellermanns, 2010). Specifically, generational involvement produces knowledge diversity (cf. Jehn, Northcraft\& Neale, 1999; Milliken \& Martins, 1996) due to the different expertise and perspectives that family members belonging to different generations bring to the team (Chirico, Sirmon, Sciascia\& Mazzola, 2011; Ling \&Kellermanns, 2010). Salvato (2004), Zahra (2005), Kellermanns and Eddleston (2006) and Kellermanns, Eddleston, Barnett and Pearson (2008) argue that generational involvement is positively related to entrepreneurial behavior. However, they hold a position that is somewhat in contrast with most literature, according to which family firms are risk-averse and resistant to change (Jones, Makri\& Gomez-Mejia, 2008; Gomez-Mejia, Haynes, Nunez-Nickel, Jacobson \&Moyano-Fuentes, 2007; Naldi et al., 2007; Short, Payne, Brigham, Lumpkin \&Broberg, 2009).

\section{The Formation of Entrepreneurial Teams: -}

Entrepreneurial teams differ from many other types of teams in businesses, in that they form voluntarily and are not imposed by others. Thus, entrepreneurial teams are naturally forming groups, but in contrast to many other naturally forming groups, they are task oriented (Hellerstedt, 2009): entrepreneurial teams' engagement in the identification, evaluation, and exploitation of opportunities is fundamental to their existence (Cooney, 2005; Wright \&Vanaelst, 2009). Kamm and Nurick (1993) illustrate that the formation of an entrepreneurial team can be ignited by the recognition of an opportunity by an individual who then seeks others to pursue the opportunity; or by two or more individuals motivated to work together who then seek an opportunity. In addition, Cooney proposed that entrepreneurial teams might be formed due to a triggering event that entices them to identify and pursue opportunities. In practice, team formation and idea generation may emerge in a dynamic, reciprocal fashion (Beckman, 2006). Entrepreneurial team formation may occur long before the formal founding of a business (Wright \&Vanaelst).

\section{The Membership of Entrepreneurial Teams: -}

Entrepreneurial team membership consists of individuals involved in the process to found or acquire a business venture together and its subsequent ownership and management (Cooney, 2005; Kamm et al., 1990; Ucbasaran et al., 2003). Studies have tended to contrast the need to have a variety of skills, experience, and ways of thinking with the desire for affinity and cohesion within the team (Forbes et al., 2006; Ucbasaran et al.). Social capital and diversity of prior affiliations provide entrepreneurial teams with access to ideas, opportunities, and resources (Beckman, 2006; Wright \&Vanaelst).

Team members are often selected from preexisting networks of kin, friends, work colleagues, employees, or existing business associates (Anderson, Jack, \&DrakopoulouDodd, 2005; Anderson \& Miller, 2003; Casson\&Giusta, 2007; Iacobucci\& Rosa, 2010) and through existing strong relationships (Forbes et al., 2006; Francis \& Sandberg, 2000).

The selection of additional team members may be related to the relative power of key stakeholders and interpersonal attractions and not based on a specific need (Forbes et al.). Ruef et al. (2003) pose that trust is paramount and strangers are avoided. Homophilymay thus be a stronger driver of entrepreneurial team membership (Ruef et al.) than RBVperspectives indicate. However, Ruef et al. (p. 202) state that "a failure to control for the presence of kinship ties in founding teams may lead to inflated estimates of homophily."

\section{The Formation of FETs: -}

Entrepreneurial teams composed of family members have not been studied to any great extent. The pursuit of opportunities by families is assumed to be concentrated on existing family businesses and motivated by family circumstances such as the development of opportunities for offspring or wider family members; the division of the (existing)business to accommodate the succession of multiple siblings; or the search for alternative income opportunities when the core business faces unfavorable market conditions (Carter\& Ram, 2003, p. 375). Hoy and Verser (1994) extend key themes of entrepreneurship to the context of family business and point to the transfer of the owner's vision to other family members, sustaining the innovativeness of the founder, intergenerational strategic thinking, and the influence of the family's values and priorities on the nature of the firm. They suggest that creating value involves "Entrepreneurship, i.e., intergenerational entrepreneurship leading to transformation" (p. 19). They do not expand on this, and it is not clear who or what will be transformed, but it offers an idea that may have the potential to provide an interesting perspective on the complex, dynamic interplay among the different generations, individuals, and businesses they are running. 
Studies of portfolio entrepreneurship have examined the motivations and attributes of habitual entrepreneurs but tended to focus on the individual rather than teams (Kolvereid\&Bullvag, 1993; MacMillan, 1986; Ucbasaran et al., 2003; Westhead \& Wright, 1998). In family business studies, the enactment of opportunities is most often presented as being by individual family members, usually the senior generation (SG). And yet it is widely acknowledged that entrepreneurship is rarely enacted by lone individuals, and throughout the world, there is evidence of family members in a whole variety of transgenerational teams developing portfolios of businesses (Discua Cruz, 2010; Nordqvist\& Zellweger,2010; Rosa, 1998).

Family business studies have shown that theories used to explain behavior in nonfamily organizations may be less valid in a family business context, most often because they do not capture the social and relational aspects of families in business. So while the formation of FETs may be driven by portfolio entrepreneurship, it is important to also consider social and relational theories that may be particularly relevant to families in business.

However, there is a danger of overgeneralizing to families in business and assuming that they are internally consistent and externally homogeneous (Westhead \&Howorth,2007). Some families will not adopt a stewardship approach to being in business together.

Some families are characterized by rivalries, nepotism, shirking, and destructive behaviors that stem out of selfinterest (Schulze et al., 2003). Davis et al. (1997) propose that stewardship relationships are more likely to prevail where individuals are motivated by higher order needs and intrinsic factors. If some family members indulge in opportunistic behavior, others exhibiting a stewardship perspective may feel betrayed and subsequently become more self-serving (Davis et al.). Where individual family members are self-serving but entrepreneurial, they are more likely to form individual businesses than a FET.

The relational dimension of familiness includes trust, norms, obligations, and identity(Pearson et al., 2008). Eddleston, Chrisman, Steier, and Chua (2010) suggest that stewardship theory, along with many of the theories of family business, is underpinned by trust. Where trust, norms, obligations, and identity are strong and focused on the collective, family members will be more committed to each other, and they may be more likely to form entrepreneurial teams. In the following sections, after considering the membership of entrepreneurial teams, we return to the dimensions of familiness in relation to the membership of FETs.

\section{Family Members in Entrepreneurial Teams: -}

Entrepreneurs looking for team members might look to family and friends, but this could provide a less heterogeneous composition of human and social capital, particularly if additional family members' experience, skills, and business-related contacts have been developed within the same family businesses. Family relationships might make it hard to exclude (or reject) members of kin, and altruism could lead junior family members being included with little human capital and to teams of family members that are less qualified.

However, junior family members may be provided with training and experience in specific areas that contribute to the human and social capital of the team (Howorth\& Ali, 2001). Structural, cognitive, and relational dimensions of familiness are not consistent across a family and may influence the inclusion or exclusion of different family members in the entrepreneurial team. In particular, the relational dimension has potential for great variation within the family. Pearson et al. (2008, p. 958) state that the relational dimension consists of resources created through personal relationships, namely trust, norms, obligations, and identity.

Theories of trust indicate that trust, norms, obligations, and identity are interdependent (Howorth\& Moro, 2006). Höhmann and Welter (2005, p. 4) state that "entrepreneurialbehavior cannot be understood without taking into account the phenomenon of trust." Eddleston et al. (2010) suggest that trust could underpin many of the theories that are used to explain behavior in family businesses and that "families throughout the world offer naturally occurring communities that generate trust relations" (Eddlestonet al., p. 1044). Trust's relevance to FETs is clear from trust's definition: "the willingness of a party to be vulnerable to the actions of another party [who] . . will perform a particular action important to the trustor, irrespective of the ability to monitor and control that other party" (Mayer, Davis, \&Schoorman, 1995, p. 712). Different forms or strengths of trust range from the weakest form, calculus trust, through knowledge-based trust, based on relationships (Lewicki\& Bunker, 1996) to the strongest form of unconditional or identification-based trust. Family members may exhibit stronger forms of trust because they are 
more willing to be vulnerable to each other's actions; there may be strong identification with each other's' ideas, desires, and intentions and a strong reciprocal understanding in terms of values and standards of behavior.

Trust is believed to be important for entrepreneurial teams (Hellerstedt, 2009; Ruefet al., 2003), but trust is multifaceted, and we do not know which factors are most relevant to selection of entrepreneurial team members in family or nonfamily firms. Mayer et al. (1995) suggest that trustworthiness comprises three factors: ability, benevolence, and integrity. Higher levels of perceived integrity may be important because of the difficulty for entrepreneurial team members to control the agency risks of joint financial ownership and management. Membership of FETs may emphasize trust in integrity and benevolence more than ability.

In contexts where institutional trust is low, there may be greater dependence on personal trust (Höhmann\&Welter, 2005) and social capital. Honduras is one such context as explained in the following section.

\section{TopManagementTeam Diversity andEntrepreneurial Orientation: -}

Upper echelon theory asserts that firm outcomes are a "reflection" of the actions of its TMT (Hambrick\& Mason, 1984; Finkelstein \&Hambrick, 1990). The theory assumes that managers act on the basis of their cognitive frames, through which situations are differently interpreted and different actions are taken. This construalis a function of TMT members' different education, experience, perspectives, values, affiliations and demographic 4 characteristics.

Some scholars support the idea that TMT diversity leads to the consideration of many alternatives and that this enhances the likelihood that innovative decisions will be made (Bantel\& Jackson, 1989; Wiersema\&Bantel, 1992). TMT diversity should indeed lead to better problem solving and higher creativity and innovation because of the constructive dialogue built around top managers multiple ideas, knowledge and perspectives not available in homogeneous TMTs (Talke, Salomo\&Rost, 2010; Talke et al., 2011). The most prominent benefit of a heterogeneous group is thus related to knowledge diversity (Milliken \& Martins, 1996), defined as the different expertise and perspectives possessed by individuals in a given domain to perform a task or activity in a team (cf. Jehn et al., 1999; Postrel, 2002). Knowledge diversity highly stimulates task-related conflicts, i.e. productive debate and criticism about the content of the task being performed (Jehn, 1995; 1997; Jehnet al., 1999), which promote knowledge integration (Grant, 1996; Nonaka, 1994) and thus entrepreneurial action (Boeker, 1997a, 1997b). For instance, Talke et al. (2011: 823) found that "top managers with diverse educational, functional, industry, and organizational backgrounds will combine different views of the world and have more constructive task conflicts, which encourages...a proactive innovation orientation of firm." Also, Boeker (1997a, 1997b) found that heterogeneous TMTs are more likely to be entrepreneurial and enter new product markets than homogeneous teams. Similarly, Simons, Pelled and Smith (1999) suggest diversity in educational background and tenure can create alternative views and foster innovative choices.

However, despite its merits, TMT diversity is also accompanied by costs. For instance, TMT diversity can produce high levels of relationship or emotional conflicts, i.e. "interpersonal incompatibilities among group members, which typically includes tension, animosity, and annoyance" (Jehn, 1995: 258) that undermine consensus and agreement, and thereby the potential entrepreneurial advantages of having a group with different knowledge and perspectives. Miller et al. (1998) for example found that more diverse TMTs make less comprehensive evaluations of opportunities and threats; and Knight et al. (1999) and Hambrick, Cho and Chen (1996: 664) showed that team heterogeneity is negatively related to strategic consensus and leads to "dispersion in the group's perspective", thus constraining or delaying entrepreneurial action. Also, Ancona and Caldwell (1992) and O'Reilly et al. (1993), among others, found that TMT diversity decreases entrepreneurship.

Such mixed results have induced most scholars to argue that TMT diversity is a 'double-edged sword' (cf. Milliken \& Martins, 1996) in which the "effect of TMT diversity on innovativeness [and entrepreneurship]" is "mixed and ambiguous because of the dual impact of the benefits and costs associated with TMT diversity" (Auh\&Menguc, 2005: 250). TMT diversity apparently brings the necessary knowledge to bear on complex strategic issues, but it is also likely to promote dysfunctional rivalries, impair social integration, and restrict knowledge flows - all of which serve to inhibit EO. In this research we aim to achieve a better understanding of this complexity and of the circumstances in which "potential benefits of diverse teams appear to be highly vulnerable to certain liabilities." (Michie, Dooley \&Fryxell, 2006: 131). 


\section{Founder Teams and Human Resource Values: -}

The early decisions made by the leadership team of a new venture are important in establishing the trajectory of development of the firm as it grows and matures, and therefore understanding how teams make these decisions regarding structures and processes will help explain firm behaviors and performance (Baron, Burton, \&Hannan,1996; Beckman et al., 2007; Francis \& Sandberg, 2000; Fren, Cardinal, \& O’Neill,2012; Hmieleski\& Ensley, 2007; West, 2007). Critical to the investigation of the composition of new venture teams is whether and when team heterogeneity or homogeneity (which includes the degree of diversity and what kind of diversity) is more effective. In the article by Leung, Foo, and Chaturvedi (2013), the assumption is that both can be important in terms of the internal consistency and distinctiveness of human resource values, which are important for the long-term performance of the firm because they will affect strategy implementation. The authors argue that common bonds through shared organizational experience indicate high-quality relationships among team members and therefore will increase the consistency and distinctiveness of human resource values.

Thus, their measure of homogeneity through shared organizational experience is quite similar in its theoretical justification if not its empirical operationalization to the measures of intra-team relationships used by Cruz et al. (2013), Lim et al. (2013), andSciascia et al. (2013).

The authors also argue that functional diversity can increase or decrease the internal consistency and distinctiveness of human resource values. The former argument is based on the notion that functional diversity represents a firm's cognitive capability, an argument similar to Lim et al. (2013) and Sciascia et al.'s (2013) idea that functional diversity is linked to constructive task conflict and more coherent decision making. However, Leunget al. (2013) recognize that it is possible that functional diversity could reduce the likelihood of strategic consensus, which would negatively impact the internal consistency and distinctiveness of human resource values. Finally, the authors investigate the interaction effects of shared organizational experience and functional diversity, arguing that high levels of both will have the greatest positive impact on the internal consistency and distinctiveness of human resource values.

The findings of Leung et al.'s (2013) are consistent with those of the other studies in this special issue. Using a sample of 60 high-tech firms from Singapore, they find that shared organizational experience increases the internal consistency and distinctiveness of human resource values, but functional diversity only increases distinctiveness. Of more interest are the results of their tests of moderation, which were statistically significant but contrary to the direction proposed in their hypotheses. Thus, venture teams with high shared organizational experience and low functional diversity reported the highest levels of internal consistency and distinctiveness of human resource values.

Combined with the other studies in the special issue, the results of Leung et al.'s work again suggests that strong relationships among team members may be a more important ingredient for success for both family and nonfamily firms than a comprehensive set of skills among team members. Interestingly, these findings seem to be valid across cultures as the results of the various studies in this issue span samples in several different continents.

\section{Team fault lines and Opportunity Identification: -}

The conceptual article by Lim et al. (2013) reminds us that entrepreneurial teams are not necessarily homogeneous in terms of their goals and preferred strategies, nor are they immune to dysfunctional conflict that can inhibit the smooth development of the venture. Indeed, Lim et al. point out that often, teams devolve into subgroups of individuals who share a common background or orientation or set of demographic attributes that differ from those of other subgroups in the team. The divisions have come to be known in the literature as fault lines (Thatcher \& Patel, 2012). Lim et al. apply the fault line concept to the sources and consequences of dissension among idea-conceiving founders and equitybasedpartners or investors.

Lim et al. (2013) propose that differences in the structure of the venture including the distribution of equity, the power to change the composition of the team, and the preexisting ties among the founders and investors can affect the strength of the fault linesbetween the two groups. Similarly, those authors argue that the extent to which founders and investors possess similar mental models with regard to the venture will also influence fault line strength. The authors go on to suggest that fault lines will influence the interactions among founders and investors in three ways: by affecting the extent of relationship conflict, task conflict, and knowledge exchange that occurs among the disparate groups. Finally, Lim et al. argue that relationship conflict, task conflict, and knowledge exchange will influence the quality of the opportunities identified by the venture, in effect acting as mediators in the relationship 
between fault line strength and opportunity identification.Sciascia, Mazzola, and Chirico (2013, this issue) suggest that family teams can be much larger and more diverse and therefore prone to suffer from fault lines between different coalitions of individuals on the top management team or board of directors. For example, family teams that include in-laws, nonfamily members, different generations, or family members with dissimilar levels of commitment may develop fault lines, whereas family teams based solely on blood and shared values may not (Cruz et al.). This raises the question of whether Lim et al.'smodel can be effectively applied to other team situations in its particulars and whether or not a wide variety of different structural and/or cognitive elements can likewise determinefault line strength.

There is also the issue of how fault lines can be diffused or when they exist how they can be used for productive rather than destructive ends. For example, Lim et al. (2013) suggest that task conflict will be low and relationship conflict high when fault linesare strong. However, this does not necessarily need to be the case, particularly with regard to task conflict, if an actual, as opposed to perceived, balance of power can be achieved among the two groups. Furthermore, by channeling disagreements toward material matters, petty strife might be minimized, and decision quality can be enhanced (Kellermanns,Floyd, Pearson, \& Spencer, 2008). On the other hand, the ability of a powerful owner-manager to discipline other team members may prevent fault lines from developing, albeit with the risk of sacrificing task conflict (e.g., Ensley \& Pearson, 2005). But we need more theory and research to understand if, when, and how the constructive management of conflict across fault lines might occur.

\section{Generational Involvement and Entrepreneurial Orientation: -}

In contrast to the studies of Cruz et al. (2013) and Lim et al. (2013) that deal with teams formed explicitly to seek and exploit entrepreneurial opportunities, Sciasciaet al. (2013) deal with the entrepreneurial orientation of preexisting teams in a sample of 199mature family firms located in Switzerland. However, their arguments and findings are highly congruent with those of the other articles contained in this issue. Sciascia et al.draw on upper echelons theory (Hambrick\& Mason, 1984) to suggest that generational involvement is a proxy for knowledge diversity and therefore that entrepreneurial orientation suffers whenever too much or too little generational involvement is present. In the first instance, the involvement of only one generation is expected to lead to groupthink and a more conservative mode of business. Here, the firm suffers from too little task conflict, too few devil's advocates, too few risk takers, and too little creativity. In the second instance, the involvement of multiple generations increases the risk of relationship conflict owing to excessive kinship distance and difficult-to-reconcile disparities in goals and strategies. Here, what might evolve into constructive discussions of alternative courses of action is likely to turn into disagreements centered on personal rivalries, distrust, and deliberate or inadvertent misunderstandings. Consequently, Sciascia et al. hypothesize and find that generational involvement has an Inverted-U shape relationship with entrepreneurial orientation.

As noted above, Sciascia et al.'s (2013) findings can be compared with those of other articles contained in this issue. For example, their study suggests that the number of generations involved in a family firm and the possibility of fault lines emerging may be correlated. Using the work of Lim et al. (2013) as a guide, several explanations are possible including the natural differences that might occur given in congruencies between the current ownership of the older generation and the (often uncertain) residual ownership of the younger generation, as well as the obvious differences in mental models that are likely to occur when individuals representing three or more generations of a family are involved. On the other hand, Sciascia et al.'s study also suggests that fault linesbetween groups with somewhat different perspectives may be healthier than no fault lines at all, as long as they are not allowed to become too deep. These considerations are in line with research on surface and deep level diversity and on conflict within entrepreneurial teams (Schjoedt\& Kraus, 2009), as well as with recent thoughts on how entrepreneurial orientation is not necessarily as homogenous and pervasive throughout the firm as many researchers have assumed (Wales, Monsen, \&McKelvie, 2011).Sciascia et al.'s (2013) study also underscores an implicit message from the study of

Cruz et al. (2013); namely that beyond the years of its founding, a family business may only engage in significant entrepreneurial activity when members from the succeeding generation join and, in effect, challenge the leadership of the incumbent generation. Combined, those studies also suggest that significant entrepreneurial activity is less likely to occur when three or more generations become involved owing to a lack of a shared vision, lower trust, and potentially very different conceptions of what family stewardship is all about. Thus, these studies indicate that entrepreneurial activity is dependent on the "right" amount of diversity within the family-based team. 


\section{Family Ties, Teams, and New Venture Creation: -}

Although the potential for relationship conflict among entrepreneurial teams consisting of unrelated individuals is high, having a team composed of family members does not ensure tranquility. In fact, given the extant literature one might conclude that relationship conflict is more likely in family firms than in nonfamily firms (Ensley \& Pearson, 2005; Kellermanns\&Eddleston, 2004). Moreover, teams of family members would also seem to lack the skill breadth seen as so important to new venture success. As a consequence, one might expect that nonfamily teams would outperform family teams. However, using social identity theory Brannon et al. (2013) suggest that this is not always or even usually the case. They argue that the nature of the relationships among team members matter in determining the effectiveness of family and nonfamily teams in new venture creation, because these influence their ability to adapt to the new roles that venturing requires.

Couples are likely to have the advantages of particularly strong relationships, shared venture goals, and the flexibility to negotiate mutually acceptable roles in the family and in the firm. By contrast, role adjustments are expected to be more difficult in biologically linked teams owing to relationships that are based on a long history of interaction that are both hard to change and prone to contain the seeds of dissention. Brannon et al. (2013) therefore expect that venture teams composed of couples will be more likely, and biologically linked teams less likely, to achieve first sales than teams composed of unrelated individuals. However, they also hypothesize that when biological teams are able to employ mechanisms, such as differential financial investment to reconcile family and firm roles among team members, their ability to achieve first sales will improve relative to teams composed of either couples or unrelated individuals. Using longitudinal data from a sample of 295 venture teams located in the United States, they were able to support all of their hypotheses.

Although their study is suggestive rather than definitive, Brannon et al. (2013) are able to provide evidence that substantiates the implications of the other studies found in this special issue. Brannon et al.'s study shows that relationships are a primary driver of the success of entrepreneurial teams. When relationships are strong and relational conflict can be avoided, the probability of team success is improved. By contrast, poor performing teams appear to lack the mechanisms necessary to overcome relational issues. What they add is a social identity explanation for why the potential for relationship conflict might either be curtailed or aggravated, depending on the circumstances.

While it seems intuitively appealing to argue that the cumulative skills of an entrepreneurial team are more important, none of the studies included in this special issue support that supposition. Cruz et al.'s (2013) work suggests that skills and abilities help determine roles and assignments in family entrepreneurial teams, but this appears to be clearly a secondary function. Furthermore, Leung et al.'s (2013) study indicates that if anything, skill diversity can undermine the utility of team relationships in ensuring the consistency and distinctiveness of the human resource values of a firm. On the other hand, Lim et al.'s (2013) conceptual model and Sciascia et al.'s (2013) empirical study seems to place more equal weightings on relational and task issues. Nevertheless, both suggest that the ability of individuals to function as a team outweighs the individual or collective abilities of the team. In line with previous research (Schjoedt\& Kraus, 2009), these studies seem to indicate that deep level diversity (e.g., values) should be limited because of its potential to increase relationship conflict between team members as they engage in problem solving. Conversely, surface level diversity (e.g., educational background), if maintained (e.g., by replacement of team members), enhances the team's decision quality and performance (Schjoedt\& Kraus, 2009). Brannon et al.'s (2013) study shows that family teams can be the best or the worst in achieving first sales, leading the authors to suggest that the types of relationships as well as the strength of relationships matter, that the ability of individuals to adapt is important, and that there are mechanisms that can be used to improve the probability of team success.

\section{Lack of Growth: Folklore and Fact: -}

The notion that family-owned businesses do not grow is supported by folklore as well as fact. The adage "from shirtsleeves to shirtsleeves in three generations" expresses the widespread perception that family firms do not survive over the long term.

As for the facts, a study of the fastest growing companies in the United States by the public accounting firm Coopers \& Lybrand (Jones, Cohen, andCoppola, 1988) found that only $1 \%$ were firms run by family successors to founders, whereas $80 \%$ were led by their entrepreneurial founders. In a 1995MassMutual Life Insurance survey of more than 1,000 family-business owners, growth was ranked sixth among seven possible business goals, with much 
higherpriority placed on increasing profitability, reducing debt, and increasing family wealth outside of the business (Greenwald, 1995).

Some of the most frequently quoted statistics on family business come from a 1987 study of a sample of family firms in Illinois (Ward, 1987). It found that over a sixty-year period, only 15\% of the sample survived as independent business owners. Two-thirds of those that did survive did not grow at all through the decades. Similar results were found in a more recent study of European firms by the London-based accounting firm Horwath Group (Benson, Crego,and Drucker, 1990).

There are many theories on why family firms do not grow and rarely survive over the long term. The following are those most frequently seen:

(1) Maturing business life cycles and increasing competition

(2) Limited capital to fund both family needs and business growth needs

(3) Weak next-generation business leadership

(4) Entrepreneurial leadership's inflexibility and resistance to change

(5) Conflicts among sibling successors

(6) Disparate family goals, values, and needs

\section{Maturing Business Life Cycles: -}

Although all businesses struggle with Schumpeter's inevitable business life cycle, family-owned firms have some special burdens. Family firms frequently pride themselves on their loyalty to employees and their strong culture and traditions (Dyer, Jr., 1988). Both practices can create resistance to change, however. As an example, family firms carry loyalty too far by retaining long-standing suppliers and advisors who are past their prime and are no longer appropriate to the needs of the business.

Another problem is that most family-business leaders know and own just one business. When it matures, they have few options but to hold on to a declining asset. Most prefer to nurse the business along rather than shift their focus to new growth possibilities because the business is their creation, their identity, and their comfort (Lansberg, 1988). Low profitability reinforces this inherent unwillingness to change by increasing dependence on the historic core business.

\section{Limited Capital: -}

Like all businesses, family firms must satisfy the growing expectations of shareholders. Unlike their non-family counterparts, however, they face the challenge of providing capital to pay their owners' death taxes. Many surveys show that the value of the typical family firm represents about $80 \%$ of the family's total assets, and when the senior generation dies, the owning family faces the most onerous death tax rate in the world (Ward, 1987).

\section{Weak Next-Generation Leadership: -}

Many surveys show that one third to one half of all family businesses don't have available next-generation successors (Arthur Andersen, 1995). Those that do still face the reality of unlikely business growth because following in the footsteps of a very successful person who also is a parent or relative is, for many, an intimidating prospect. The next-generation leader must cope with many doubts and pressures:

- How can I make my mark in the land of a legend?

- How can I show respect for predecessors, yet remain my own person and foster change as a leader?

- How do I deflect the notoriety of a famous name and the constant comparisons with my namesake?

- How do I accept the responsibilities of leadership and for the welfare of others when the beneficiaries are my loved ones?

- How do I replace as leader of the family a person of an older generation who had not only the power of a parent or a senior, but also the authority of earned business success?

The odds of personal failure and the inevitability of disappointing others deeply affects the next-generation leader's style and decision making. Often, the result is a reluctance to take risks. Without risk-taking, however, the prospects for business growth wane.

Although many point to the 


\section{Inflexibility and Resistance to Change: -}

Business psychologists have observed that successful leaders with very successful business strategies become fixated on that formula for success (Danco, strategy becomes inflexible, stifling growth. Other classic entrepreneurial characteristics also block growth opportunities.

For example, many entrepreneurial personalities reject planning as a managerial practice, often arguing persuasively that it brings more disadvantages than advantages (Mintzberg, 1994):

- Planning requires sharing information. Entrepreneurs frequently prize secrecy.

- Planning forces entrepreneurs to respond to the ideas of others and to defend their own views. Entrepreneurs often relish ambiguity.

- Planning increases the opportunity for conflict among management and family. Entrepreneurs tend to avoid negatives and conflicts.

- Planning concentrates limited resources in a more focused manner. Entrepreneurs prefer spreading risk among many products, customers, and lines of business.

- Planning implies long-term commitments. Entrepreneurs like to keep as many options open as long as possible.

\section{Sibling Successor Conflict: -}

Studies show that, more often than ever, U.S. family firms are owned by a team of siblings (Nelton, 1996). Nearly half of all business owners expect to pass on leadership and ownership to two or more of their offspring.

The challenges facing sibling partnership teams are unique. Relationships among siblings are intense, and if serious discord occurs it frequently is fatal to the existing ownership structure. Approximately half of all sibling partnerships result in a split-up (Ward and Aronoff, 1992), which not only disrupts the management process and business climate, but usually consumes tremendous capital and growth potential as one or more partners are bought out by the other(s).

For a sibling partnership to work, the teammates must continually invest in their relationship. They must be able to compromise, talk things through, and follow a code of mutual understanding. Fundamentally, they must "agree to agree," because it is more vital to preserve the sibling relationship than to make optimal business decisions (Ward and Aronoff, 1992). In fact, it is better to short-change business growth if it preserves the strength of the partnership.

Good partnerships can overcome average business decisions, but bad partnerships will destroy even the best business.

\section{Disparate Family Goals: -}

Sibling and cousin-owned family businesses share an important challenge: How to reconcile the different goals, needs, and values of several family members. As families expand and grow older, goals and values inevitably become more diverse.

For most non-family-owned businesses, shareholders come and go as the nature of the investment suits their expectations. For most family-owned businesses, on the other hand, the investment is illiquid, carries emotional significance, and represents most of the shareholders' wealth. Consequently, family shareholders struggle over whether to retain their investment.

If they choose to sell, they feel disloyal to their heritage and worry about getting full value for their shares. If they choose to stay with their investment, they feel they deserve special rewards and acknowledgment (Murdoch and Murdoch, 1991). Rewards may include hefty and consistent dividends, while acknowledgment may include involvement in business governance or extra efforts made to communicate information to them about the business. Both bring challenges to growth. Providing capital for share redemption draws funds from building the business, and paying dividends diverts profits from reinvestment. Time spent earning shareholder commitment diverts energies from day-to-day business.

The most serious threat to growth occurs when some family members feel the business is unfair to their cause or does not exemplify their beliefs. These owners attack management relentlessly. Just as detrimental are family owners who feel mistreated by previous generations and focus their resentments on current family managers who they perceive as unfairly privileged representatives of their forebears. 


\section{Avoiding Stagnation: The Growth Model: -}

For most family-owned businesses, the path to survival is one of stagnation. How do these firms survive when they do not grow for so many years? The answer is in examining two unusual circumstances that benefit non-growing survivors.

First, the non-growing firms that have survived have kept ownership in one person's hands, rather than evolving into sibling partnerships or firms held widely by a variety of family members. In general, ownership by one family member who leads the business significantly increases the chances of growth and survival.

Second, the nature of their businesses and industries have spared them much competitive or technological change. In sum, most of the long-lasting survivors have avoided many of the business and family challenges faced by both family and non-family businesses (Ward, 1987).

In contrast, the family firms that have grown the most over time follow a different but no less predictable path: Each generation of leadership brings to the business new strategic ideas that build on underlying, long-held competencies developed for earlier strategies (Hamel, Jr., 1994). In addition, ownership control rests with one family manager, or if not one, as few as possible (Stoy Hayward, 1989). A good example of this growth model is Rosenbluth Travel, a $\$ 1.3$ billion Philadelphia-based firm that is more than one hundred years old. The first generation founder began by arranging steamship passage for immigrants. To succeed, the business developed excellent skills in customer service and in accounting for customers' monies.

A later generation shifted the focus to leisure travel. The same skills were important to success: providing outstanding personal service and applying the data processing and record-keeping talent to analyze customers' needs and ratestructures. The current-generation leader added a new dimension, corporate travel. This new strategy draws on the firm's historic skills. Besides providing good customer service to corporate accounts, Rosenbluth maintains excellent recordkeeping and data processing in order to deliver on its "lowest possible fares" promise to its customers.

While the growth model exemplified by Rosenbluth accurately reflects the experience of most long-growing family firms, it does not explain the day to-day management practices that spark that growth. Nor does it explain the leadership practices necessary to hold together more complicated forms of family ownership, such as sibling partnerships or more widespread family ownership. The next section outlines the best practices needed to make the growth model succeed.

Best Practices: -

Family-owned firms that grow through the decades must address each of the following requirements in order to promote expansion and overcome the special challenges inherent in family firms.

Assure Fresh Strategic Insights. Long-term growth requires ongoing sources of fresh strategic insights. In most industries, strategies must change every few years, if not continuously. Efforts to stimulate new thinking are particularly important for family-owned firms, because few successors have much breadth or variety of outside experience and most managers and leaders have long tenures. Family-business leaders can create an atmosphere that fosters and welcomes new ideas if they:

Promote strategic experimentation. Growing companies constantly test and stretch their current strategic limits (Mintzberg and Waters, 1990). They revise products, explore new markets or channels of distribution, refine the marketing mix of pricing and promotion, and create new ways to add value or differentiation.

New insights come most often from the trial-and-error experiments with current strategy, and experimentation helps jolt family firms out of the complacency that comes so naturally to many successful individuals and firms.

Budget strategic expenses. To assure that strategic development is a highly conscious process, successful firms establish a "strategic budget" that clearly identifies initiatives to promote strategic development (Mintzberg and Waters,1990). Strategic expenses are spent on efforts that, for example, promise to increase market share volume in future years or to build new lines of business. 
They do not include costs to maintain and protect the status quo. Many family firms find that setting up a strategic budget provides helpful tension to preserve needed funds in the family business against the temptation to pay increasing dividends or family-member bonuses and perks.

Provide serendipity capital. Creative managers need discretionary funds to explore and experiment with new ideas and to react to new circumstances that were not anticipated in the annual operating budget process. Some outstanding growth firms include such discretionary funds for each manager as part of their operating budgets. Managers are encouraged to spend these funds for the sake of the future, which creates a climate of experimentation and motivates creative, dynamic managers to achieve their best.

Use independent directors on the board to challenge strategic assumptions. The greatest way to avoid stagnation and decline is to have an absolute business mission. Business leaders who are committed to growth urge their independent outside directors to challenge the relevance of their mission and the validity of the assumptions underscoring it. Successful business leaders know that no one can challenge their thinking and the direction of the business better than highly respected outside directors.

Encourage global experience for next-generation business leaders. A famous study by Professor Miguel Gallo (Gallo and Point, 1994) of IESE in Barcelona found that the most successful international family firms were those in which the leaders' offspring had significant work or educational experience outside of their home country. However, most family-owned firms run a high risk of limiting international growth opportunities because successors often do not gain significant outside external experience.

Attract and Retain Excellent Non-Family Managers. Long-term growth demands a pool of talented non-family managers, but most family firms do not take this resource fairly enough. They are reluctant to invest in future talent when they are unsure of the effects of strong non-family managers on the family members' career paths. Frequently, business owners are too modest to believe they can attract people of the highest caliber (Tanner, 1994). To combat their tendencies, family business leaders must:

Emphasize merit in personnel decisions. The best non-family managers need to feel that they are valued, appreciated, and compensated on the basis of merit.

Provide opportunities for the best managers to accumulate personal wealth. Few family firms give stock or stock options to their key executives (Carlson andNager, 1993). More often, they are given opportunities to participate in "phantom stock" plans or to invest alongside family members in special arrangements such as a new venture or a real estate opportunity.

Assure career growth opportunities for the best non-family executives. Talented on-family managers need assurance that they can continue to grow as professionals. Too often, the company's organization chart and the likely career paths of young family members do not give them that assurance. In response, some family firms restrict family members from entry into the business until they have ample, successful external experience. They also work hard to create more top management leadership positions than could be filled by family members alone.

Create a Flexible, Innovative Organization. Constant strategic experimentation requires a flexible, innovative organization that can:

Share business information openly. As noted earlier, secrecy is a common trait of business owners. They fear disclosing financial success, because it leads to demands by valuable employees, and financial failure, because it drives away good people. But without information and trust, creativity and loyalty are limited. Successful familyowned firms grow by sharing vital information among a large number of managers.

Champion change and celebrate new ideas. For innovation and flexibility to flourish, teamwork must be a part of the company's culture. Growing companiesde-emphasize heroic leaders as the reasons for success (Danco, 1994). Instead, they credit the organizational team and the habit of past innovation that extends to the founding of the business itself.

Constantly change some things. The best way to encourage innovation is to foster positive feelings about change. One popular approach to increasing comfort with ongoing change is to tinker regularly with management systems 
and processes, such as compensation bonus systems, information systems, organizational roles and structure, and reporting and personal performance review processes (Nelson, 1994).

Create and Conserve Capital. As the family grows, as death taxes arise, and as new strategies require increased financial resources, the demands for more capital are high. However, conserving as much cash as possible for the business is critical for growth. To help resolve the dilemma between family financial needs and growth's fiscal requirements, long-lasting, growing family firms become adept at creating and conserving capital. Among their strategies:

Use other people's money. Growing firms use more debt (Tennenbaum andTrien, 1992). They also are creative in securing capital from others who want to invest in the business's success, sometimes by offering ownership shares and opportunities for joint ventures.

Manage strategy to be less capital intensive. Over time, long-growing family firms shift their strategy to require less capital for growth (Flamholtz, 1986). They de-emphasize aspects that require significant capital (such as real estate or totally integrated production) and emphasize those that require less capital (such as servicing and franchising).

Quickly establish a share redemption plan and dividend policy. The sooner the formula for redemption is established, the less capital it will require. Long established redemption plans usually are less contentious and designed to give the business ample time and favored terms to make payouts. In addition, clear dividend policies usually lead to more content and less demanding shareholders (Family Business Advisor, 1994).

Implement estate plans early. Family-business experts agree that one of the best ways to conserve capital is to lessen the bite of death taxes by implementing the estate plan and its funding mechanism(s) as soon as possible (Blackman,1994). The sooner the plan is implemented, the more taxes that can be saved. Prompt action also minimizes the cost of necessary insurance.

Prepare Successors for Leadership. Successors to family firms face unique job requirements that require specific skills to maximize their chances of leading business growth. Most of the education for successors is either unsupervised, on-the-job training or formal course work at a university or college (Cohn, 1992). Both neglect some critical aspects of the job of CEO of a family firm. To fill the gaps, family business leaders must:

Support the successor in developing a culture of change in the business. For family successors of successful parents, leading organizational change is extremely difficult. Promoting change is usually perceived as an indictment of the past ora criticism of the predecessor. Predecessors can help by focusing on how the company team contributes to the firm's success and by discouraging credit for themselves.

Promote good mentoring for the successor. Successors benefit from several mentoring experiences: working elsewhere before entering the family firm; learning how to cope with the expectations of the outside world of civic organizations, charities, and trade associations; and learning how to create a common strategic vision for the company and the owners.

Set a date to transfer both responsibility and control to the next generation. Successors can be inhibited by uncertainty over the date of succession. Predecessors who establish the date far in advance usually are more calm and prepared for retirement, and their successors are more motivated and committed to be the leaders the business and its growth require. Nothing frustrates the growth of a family firm more than the unwillingness or inability to empower and to entrust the next generation with control and authority (Jaffe, 1990).

Exploit the Unique Strategic Advantages of Family Ownership. Much of the early part of this paper outlined the disadvantages and special challenges to growth for many family firms. Successful family-owned companies know there are special advantages, too, and they strive to shape strategies that exploit them, such as:

Seeking investments that reward patient capital. Family firms have a unique opportunity to be long-term oriented. Security analysts can't punish their long term thinking. For a strong family, long-term value is much preferred to short term results. Highly successful family firms can therefore be more consistent in their business-building efforts and react less to bumps in the economy or their industry. Such efforts can include research and development, brand name development, market expansion, and even investments in out-of-fashion businesses, such as savings and loans and metal platers. 
Build strategy around relationships. For the family-owned business, reputation is all-important (Donnelley, 1964). With the family name on the door and with the realization that future generations will be known, in part, by today's decisions, families in business have every advantage in dealing with each other. Mutual trust can lead to exciting new growth opportunities: More and more global alliances are being established by family firms.

Concentrate on businesses in which fast decision making is a plus. While quick decision-making certainly is a function of small firms, it also is a function of family firms. Decreased organizational politics and the resonance of ownership with managerial leadership allow family businesses to respond when quick decision-making is required.

\section{Conclusion: -}

The number of family members in TMT certainly affects tending to EO. The findings represent that attending non family members in such teams not only promotes diversity in TMT but also results in rationality and no prejudice in decision making which reflects a significant decrease in family conflicts and increases professionality level in doing business that finally causes changes and innovation. Non family managers basically improve the quality of strategic decisions and also managerial behaviors. Family managers prefer not to disturb social and financial welfare and family asset of future generations.

The relation between team members is more important than extension of skills in team success regardless of attending family or non-family members in team structure. There may be opportunities missed by focusing excessively on the downside rather than on the upside of competing coalitions in the firm.

A family team work needs altruism of family members, so to be more effective team should avoid family conflicts and its derived risks.

The businesses which stablished by family entrepreneurial groups are radically in the shade of family relations. Teams in which involve couples reflect completely different behaviors rather than other teams. The relations between the members of a team directly affect their output also investing on start up large family entrepreneurial team's helps improvement of the business and can harmonize both career and family personality of individuals.

The leaders of family businesses who conduct their own businesses by themselves, can produce specific output by utilizing the best methods. There are many specific characteristics for abovementioned leaders which are listed some of them as below: Their personal mission is to build an enduring institution that will last and be even more successful in the future (Tagiuri and Davis, 1992). On the other hand, they believe in responsibility for standing on the top either of the position or of the leadership since they have come to scene.

It is essential for entrepreneurship orientation of family businesses to attend more than one generation in those businesses and it demonstrates that to be successful during the time, they ' $d$ rather strengthen their knowledge acceptability potential.

Family managers and owners are recommended to limit the existence of family generations by two, because attending 3 generations of one family in TMT may lead to lose efficiency of family relations in such companies. The most important factor in long lasting growth of a business is arranging family meetings which support goal and mission of the family, its values, motivations and logical reason for ongoing the ownership of business. By making agreement and desirable satisfaction it would be easier to make a better path toward achieving growth in the long run.

Finally, researchers in this area are suggested to investigate personal characteristics of entrepreneurs of family businesses and also to find methods of training managers among subsequent generation in order to study its impact on permanence of business growth. 


\section{References: -}

1. Baron, J.N., Burton, M.D., \&Hannan, M.T. (1996). The road taken: Origins and evolution of employment systems in emerging companies. Industrial and Corporate Change, 5, 239-275.

2. Beckman, C.M., Burton, M.D., \& O'Reilly, C. (2007). Early teams: The impact of team demography on VC financing and going public. Journal of Business Venturing, 22, 147-173.

3. Birley, S. \&Stockley, S. (2000). Entrepreneurial teams and venture growth. In D.L. Sexton (Ed.), The Blackwell handbook of entrepreneurship (pp. 287-307). Oxford, U.K.: Blackwell Business.

4. Brannon, D.L., Wiklund, J., \&Haynie, J.M. (2013). The varying effects of family relationships in entrepreneurial teams. Entrepreneurship Theory and Practice, 37(1), 107-132.

5. Bygrave, W.D. (1993). Theory building in the entrepreneurship paradigm. Journal of Business Venturing, 8 , 255-280.

6. Cohen, S.G. \& Bailey, D.E. (1997). What makes teams work: Group effectiveness from the shop floor to the executive suite. Journal of Management, 23, 239-290.

7. Cooney, T.M. (2005). What is an entrepreneurial team? International Small Business Journal, 23, 226-235.

8. Cooper, A.C. \& Daily, C.M. (1997). Entrepreneurial teams. In D.L. Sexton \& R.W. Smilor (Eds.), Entrepreneurship

9. 2000 (pp. 127-150). Chicago, IL: Upstart.

10. Cruz, A.D., Howorth, C., \& Hamilton, E. (2013 this issue). Interfamily entrepreneurship: The formation and membership of family entrepreneurial teams. Entrepreneurship Theory and Practice, 37(1), 17-46.

11. Cyert, R.M. \& March, J.G. (1963). A behavioral theory of the firm. Englewood Cliffs, NJ: Prentice-Hall.

12. Dess, G.G., Lumpkin, G.T., \& McGee, J.E. (1999). Linking corporate entrepreneurship to strategy, structure, and process: Suggested research directions. Entrepreneurship Theory and Practice, 23(3), 85-102.

13. Ensley, M.D. \& Pearson, A.W. (2005). An exploratory comparison of the behavioral dynamics of top management teams in family and nonfamily new ventures: Cohesion, conflict, potency, and consensus. Entrepreneurship Theory and Practice, 29, 267-284.

14. Forbes, D.P., Borchert, P.S., Zellmer-Bruhn, M.E., \& Sapienza, H. (2006). Entrepreneurial team formation: An exploration of new member addition. Entrepreneurship Theory and Practice, 30, 225-248.

15. Francis, D.H. \&Sandberg,W.R. (2000). Friendship within entrepreneurial teams and its association with team and venture performance. Entrepreneurship Theory and Practice, 25(2), 5-25.

16. Fren, M.J., Cardinal, L.B., \& O’Neill, H.M. (2012). The genesis of strategy in new ventures: Escaping the constraints of founder and team knowledge. Strategic Management Journal, 33, 427-447.

17. Hambrick, D.C. (1994). Top management groups: A conceptual integration and reconsideration of the "team" label. Research in Organizational Behavior, 16, 171-214.

18. Hambrick, D.C. (2007). Upper echelons theory: An update. Academy of Management Review, 32, 334-343.

19. Hambrick, D.C. \& Mason, P.A. (1984). Upper echelons: The organization as a reflection of its top managers. Academy of Management Review, 9, 193-207.

20. Hmieleski, K.M. \& Ensley, M.D. (2007). A contextual examination of new venture performance: Entrepreneur leadership behavior, top management team heterogeneity, and environmental dynamism. Journal ofOrganizational Behavior, 28, 865-889.

21. Kamm, J.B. \&Nurick, A.J. (1993). The stages of team venture formation: A decision-making model. Entrepreneurship Theory and Practice, 17(2), 17-28.

22. Kamm, J.B., Shuman, J.C., Seeger, J.A., \&Nurick, A.J. (1990). Entrepreneurial teams in new venture creation: A research agenda. Entrepreneurship Theory and Practice, 14(4), 7-17.

23. Katzenbach, J.R. \& Smith, D.K. (1993). The wisdom of teams. New York, NY: First Harper Business.

24. Kellermanns, F.W. \&Eddleston, K.A. (2004). Feuding families: When conflict does a family firm good. Entrepreneurship Theory and Practice, 28, 209-229.

25. Kellermanns, F.W., Floyd, S., Pearson, A.W., \& Spencer, B. (2008). The contingent effect of constructive confrontation on the relationship between shared mental models and decision quality. Journal of Organizational

26. Behavior, 29, 119-137.

27. Leung, A., Foo, M.D., \&Chaturvedi, S. (2013). Imprinting effects of founding core teams on HR values in new ventures. Entrepreneurship Theory and Practice, 37(1), 87-106.

28. Lim, J.Y.-K., Busenitz, L.W., \& Chidambaram, L. (2013). New venture teams and the quality of business opportunities identified: fault lines between subgroups of founders and investors. Entrepreneurship Theoryand Practice, 37(1), 47-67.

29. Mathieu, J., Maynard, M.T., Rapp, T., \& Gilson, L. (2008). Team effectiveness 1997-2007: Areview of recent advancements and a glimpse into the future. Journal of Management, 34, 410-476. 
30. Pearson, A.W., Carr, J.C., \& Shaw, J.C. (2008). Toward a theory of familiness: A social capital perspective. Entrepreneurship Theory and Practice, 32, 949-969.

31. Ruef, M., Aldrich, H.E., \& Carter, N.M. (2003). The structure of founding teams: Homophily, strong ties, and isolation among US entrepreneurs. American Sociological Review, 68, 195-222.

32. Schjoedt, L. \& Kraus, S. (2009). Entrepreneurial teams: Definition and performance factors. Management Research News, 32, 513-524.

33. Schulze, W.S., Lubatkin, M.H., Dino, R.N., \&Buchholtz, A.K. (2001). Agency relationships in family firms:

34. Theory and evidence. Organizational Science, 12, 99-116.

35. Sciascia, S., Mazzola, P., \& Chirico, F. (2013). Generational involvement in the top management team of family firms: Exploring non-linear effects on entrepreneurial orientation. Entrepreneurship Theory and Practice.

36. Thatcher, S.M.B. \& Patel, P.C. (2012). Group fault lines: A review, integration, and guide to future research. Journal of Management, 38, 969-1009.

37. Ucbasaran, D., Lockett, A., Wright, M., \& Westhead, P. (2003). Entrepreneurial founder teams: Factors associated with member entry and exit. Entrepreneurship Theory and Practice, 28, 107-127.

38. Wales, W., Monsen, E., \&McKelvie, A. (2011). The organizational pervasiveness of entrepreneurial orientation. Entrepreneurship Theory and Practice, 35, 895-923.

39. West, G.P. (2007). Collective cognition: When entrepreneurial teams, not individuals, make decisions. Entrepreneurship Theory and Practice, 31, 77-102.

40. Arthur Andersen \& Co., S.C. (1995). Research Findings. American Family Business Survey, Chicago.

41. Aronoff, C. E. \&Astrachan, J. H. (1996). How to make better decisions. Nation's Business,

42. 84(1), 39-40.

43. Benson, B., Crego, E. T., \& Drucker, R. H. (1990). Your Family Business: A Success Guide for Growth and Survival. Homewood, IL: Dow-Jones-Irwin.

44. Blackman, I. L. (1994). Two magic bullets . . or How to beat the tax collector. National Petroleum News, $86(2), 44$.

45. Carlson, D. K., \&Nager, R. W. (1993). Equity compensation for key employees. Family Business Advisor. (January).

46. Cohn, M. (1992). Passing the Torch: Succession, Retirement, and Estate Planning in the Family-Owned Business. New York: McGraw-Hill.

47. Danco, L. A. (1994). Why few firms outlive their founder. Tire Business, 8.

48. Donnelley, R. G. (1964). The family business. Harvard Business Review, 42(4), 10-11.

49. Dyer, W. Gibb, Jr. (1988). Culture and continuity in family firms. Family Business Review, 1(1), 37-50.

50. Family Business Advisor. (1994). Thinking about dividend policies. Family Business Advisor,

51. 3(3), 1 .

52. Flamholtz, E. G. (1986). How to Make the Transition From a Entrepreneurship to a Professionally Managed Firm. San Francisco: Jossey-Bass.

53. Gallo, M. A., \& Point, C. G. (1994). Internationalizing family firms. Family Business Advisor, 3(4), 1.

54. Greenwald, Matthew and Associates (1995). Research Findings. MassMutual Life Insurance Company, 47.

55. Hamel, L. H., Jr. (1994). The first generation. Family Business Report, (November), 7.

56. Jaffe, D. (1990). Working with the Ones You Love. Berkeley, CA: Conari Press.

57. Lansberg, I. (1988). The succession conspiracy. Family Business Review, 1(2), 119-143.

58. Maslow, A. H. (1954) Motivation and Personality. New York: Harper.

59. Mintzberg, H. \& Waters, J. A. (1990). Tracking strategy in an entrepreneurial firm. Family Business Review, $3(3), 285-313$.

60. Mintzberg, H. (1994). The Rise and Fall of Strategic Planning. New York: The Free Press.

61. Murdoch, M., \& Murdoch, C. M. (1991). A legal perspective on shareholder relationships in family businesses: The scope of fiduciary duties. Family Business Review, 4(3), 287-301.

62. Nelson, R. (1994). Creating an energized workplace. Leader to Leader, 5 (Summer), 34-39.

63. Nelton, S. (1996). Team playing is on the rise. Nation's Business, 84(6), 53-55. Stoy Hayward \& Associates (1989). Staying the course: Survival characteristics of the family owned business. Report conducted by the Graduate Students of the London School of Business, 22-23.

64. Tanner, F. L. F. (1994). Do you have an effective compensation plan for you key employees? Family Business Forum Quarterly, 7(3), 8.

65. Tennenbaum, B. H., \& Trien, J. W. (1992). How to woo your banker?Family Business Magazine, (Summer), $31-36$. 
66. Ward, J. L. 1987. Keeping the family business healthy: How to plan for continuing growth, profitability, and family leadership. San Francisco: Jossey-Bass.

67. Ward, J. L., \&Aronoff, C. E. (1992). Sibling partnerships. Nation's Business, 80(1), 52-53.

68. Ancona, D.G., \& Caldwell, D.C. (1992). Demography and design: predictors of new product team performance. Organization Science, 3 321-341.

69. Auh, S., \&Menguc, B. (2005). Top management team diversity and innovativeness: The moderating role of interfunctional coordination. Industrial Marketing Management, 34, 249-261.

70. Bantel, K.A., \& Jackson, S.E. (1989). Top management and innovations in banking: does the composition of the top team make a difference? Strategic Management Journal, Summer Special Issue, 10, 107-124.

71. Beckman, C.M. (2006). The influence of founding team company affiliations on firm behavior. Academy of Management Journal, 49 (4), 741-758.

72. Beckman, C.M., Burton, M.D., \&O'Reilly, C. (2007). Early teams: The impact of team demography on VC financing and going public. Journal of Business Venturing, 22(2), 147- 173.

73. Boeker, W. (1997a). Executive migration and strategic change: the effect of top manager movement on product market entry. Administrative Science Quarterly, 42, 231-236.

74. Boeker, W. (1997b). Strategic change: the influence of managerial characteristics and organizational growth. Academy of Management Journal, 40, 152-170.

75. Chirico F., Sirmon D., Sciascia S., \& Mazzola P. (2011). Resource orchestration in family firms: Investigating how entrepreneurial orientation, generational involvement and participative strategy affect performance. Strategic Entrepreneurship Journal, 5(4), 307-326.

76. Chrisman, J. J., Chua, J. H., \&Steier, L. P. (2011). Resilience of family firms: An introduction. Entrepreneurship Theory and Practice, 35, 1107-1119.

77. Cruz, C., \&Nordqvist, M. (2012). Entrepreneurial orientation in family firms: A generational perspective. Small Business Economics 38(1), 33-49.

78. Ensley, M. D., \& Pearson, A. W. (2005). An exploratory comparison of the behavioral dynamics of top management teams in family and nonfamily new ventures: Cohesion, conflict, potency, and consensus. Entrepreneurship Theory \& Practice, 29, 267-284.

79. Finkelstein, S., \&Hambrick, D. C. (1990). Top management team tenure and organizational outcomes: The moderating role of managerial discretion. Administrative Science Quarterly, 35, 484-503.

80. Gomez-Mejia, L.R., Haynes, K.T., Nunez-Nickel, M., Jacobson, K.J.L., \&Moyano-Fuentes, J. (2007). Socioemotional wealth and business risks in family-controlled firms: Evidence from Spanish olive oil mills. Administrative Science Quarterly 52, 106-137.

81. Grant, R. (1996). Prospering in dynamically competitive environments: organizational capability as knowledge integration. Organization Science, 7(4), 375-387.

82. Hambrick, D.C., Cho, S.T., \& Chen, M.J. (1996). The influence of TMT heterogeneity on firm's competitive moves. Administrative Science Quarterly, 41, 659-684.

83. Hambrick, D.C., \& Mason, P.A. (1984). Upper echelons: The organization as a reflection of its top managers. Academy of Management Review, 9(2), 193-207.

84. Jehn, K.A. (1995). A multimethod examination of the benefits and detriments of intragroup conflict. Administrative Science Quarterly, 40, 256-282.

85. Jehn, K.A. (1997). A qualitative analysis of conflict types and dimensions in organizational groups. Administrative Science Quarterly, 42, 530-557.

86. Jehn, K.A., Northcraft, G.B., \& Neale, M.A. (1999). Why differences make difference: a field study of diversity, conflict, and performance in workgroups. Administrative Science Quarterly, 44, 741-763.

87. Jones, C.D., Makri, M., \& Gomez-Mejia, L.R. (2008). Affiliate directors and perceived risk bearing in publicly traded, family-controlled firms: The case of diversification. Entrepreneurship Theory and Practice, 32(6), 1007-1026.

88. Kellermanns, F. W., \&Eddleston, K. (2004). Feuding families: When conflict does a family firm good. Entrepreneurship Theory and Practice, 28(3), 209-228.

89. Kellermanns, F.W., \&Eddleston, K.A. (2006) corporate entrepreneurship in family firms: A Family perspective. Entrepreneurship Theory and Practice, 30(6), 809-830.

90. Kellermanns, F.W., Eddleston, K.A, Barnett, T., \& Pearson, A. (2008). An exploratory study of family member characteristics and involvement: Effects on entrepreneurial behavior in family firms. Family Business Review, 21(1), 1-14. 
91. Knight, D., Pearce, C.L., Smith, K.G., Olian, J.D., Sims, H.P., Smith, K.A., \& Flood, P. (1999). Top management team diversity, group process, and strategic consensus. Strategic Management Journal, 20(5), 445-465.

92. La Porta, R., Lopez-de-Silanes, F., \& Shleifer, A. (1999). Corporate ownership around the world. The Journal of Finance, 54(2), 471-517.

93. Ling, Y., \&Kellermanns, F.W. (2010). The effects of family firm specific diversity: The moderating role of information exchange frequency. Journal of Management Studies, 47, 332-344.

94. Michie, S., Dooley, R.S., \&Fryxell, G.E. (2006). Unified diversity in top-level teams: Enhancing collaboration and quality in strategic decision making. International Journal of Organizational Analysis, 14, 130-149.

95. Miller, C.C., Burke, L.M., \& Glick, W.H. (1998). Cognitive diversity among upper-echelon executives: implications for strategic decision process. Strategic Management Journal, 19(1), 39-58.

96. Milliken, F.J., \& Martins, L.L. (1996). Searching for common threads: Understanding the multiple effects of diversity in organizational groups. Academy of Management Review, 21, 402-433.

97. Naldi, L., Nordqvist, M., Sjöberg, K., \&Wiklund, J. (2007). Entrepreneurial orientation, risk taking, and performance in family firms. Family Business Review, 20 (1), 33-48.

98. Nonaka, J. (1994). A dynamic theory of organizational knowledge creation. Organization Science, 1, $14-37$.

99. Postrel, S. (2002). Islands of shared knowledge: Specialization and mutual understanding in problem-solving teams. Organization Science, 13, 303-320.

100.Salvato, C. (2004). Predictors of entrepreneurship in family firms. Journal of Private Equity, 7(3), 68-76.

101.Sharma, P., \&Salvato, C. (2011). Commentary: exploiting and exploring new opportunities over life cycle stages of family firms. Entrepreneurship Theory and Practice, 35, 1199-1205.

102.Short, J.C., Payne, G.T., Brigham, K.H., Lumpkin, G.T., \&Broberg, C. (2009). Family firms and entrepreneurial orientation: A comparative analysis of the S\&P 500. Family Business Review, 22(1), 9-24.

103.Simons, T., Pelled, L. H., \& Smith, K. A. (1999). Making use of difference: Diversity, debate, and decision comprehensiveness in top management teams. Academy of Management Journal, 42, 662-673.

104.Talke, K., Salomo, S., \&Rost, K. (2010). How top management team diversity affects innovativeness and performance via the strategic choice to focus on innovation fields. Research Policy, 39, 907-918.

105.Talke, K., Salomo, S., \&Kock, A. (2011). Top Management Team diversity and strategic innovation orientation: The relationship and consequences for innovativeness and performance. Journal of Product Innovation Management, 28, 819-832.

106.Wiersema, M.F., \&Bantel, K. (1992). Top management team demography and corporate strategic change. Academy of Management Journal, 35, 91-121.

107.Zahra, S.A. (2005). Entrepreneurial risk taking in family firms. Family Business Review, 18,23-40.

108. Anderson, A., Jack, S., \&Drakopoulou-Dodd, S. (2005). The role of family members in entrepreneurial

109.networks: Beyond the boundaries of the family firm. Family Business Review, 18(2), 135-154.

110.Anderson, A.R. \& Miller, C.J. (2003). "Class matters": Human and social capital in the entrepreneurial

111.process. Journal of Socio-Economics, 32(1), 17-36.

112.Beckman, C.M. (2006). The influence of founding team company affiliations on firm behavior. Academy of Management Journal, 49(4), 741-758.

113.Carter, S. \& Ram, M. (2003). Reassessing portfolio entrepreneurship. Small Business Economics, 21(4), 371380.

114.Casson, M. \&Giusta, M.D. (2007). Entrepreneurship and social capital: Analyzing the impact of social

115.networks on entrepreneurial activity from a rational action perspective. International Small Business Journal, $25(3), 220-244$.

116.Cooney, T.M. (2005). Editorial: What is an entrepreneurial team? International Small Business Journal, 23(3), 226-235.

117.Davis, J.H., Schoorman, F.D., \& Donaldson, L. (1997). Toward a stewardship theory of management. Academy of Management Review, 22(1), 20-47.

118.Discua Cruz, A. (2010). Collective perspectives in portfolio entrepreneurship: A study of family business groups in Honduras. EDAMBA Journal, Thesis competition, 8, 91-105.

119.Eddleston, K.A., Chrisman, J.J., Steier, L.P., \& Chua, J.H. (2010). Governance and trust in family firms: An introduction. Entrepreneurship Theory and Practice, 34(6), 1043-1056.

120.Forbes, D.P., Borchert, P.S., Zellmer-Bruhn, M.E., \& Sapienza, H. (2006). Entrepreneurial team formation: An exploration of new member addition. Entrepreneurship Theory and Practice, 20(2), 225- 248.

121.Francis, D.H. \&Sandberg,W.R. (2000). Friendship within entrepreneurial teams and its association with team and venture performance. Entrepreneurship Theory and Practice, 25(2), 5-25. 
122.Hellerstedt, K. (2009). The composition of new venture teams: Its dynamics and consequences. JIBS Dissertation Series 056, Jonkoping: Jonkoping International Business School.

123.Höhmann, H.-H. \& Welter, F. (2005). Trust and entrepreneurship: A West-East perspective. Cheltenham, U.K.: Edward Elgar.

124.Howorth, C. \& Ali, Z.A. (2001). Family business succession in Portugal: An examination of case studies in the furniture industry. Family Business Review, 14(3), 231-244.

125.Howorth, C. \& Moro, A. (2006). Trust within entrepreneur bank relationships: Insights from Italy. Entrepreneurship Theory and Practice, 30(4), 495-517.

126.Hoy, F. \&Verser, T.G. (1994). Emerging business, emerging field: Entrepreneurship and the family firm. Entrepreneurship Theory and Practice, 19(1), 9-23.

127.Iacobucci, D. \& Rosa, P. (2010). The growth of business groups by habitual entrepreneurs: The role of entrepreneurial teams. Entrepreneurship Theory and Practice, 34(2), 351-377.

128.Kamm, J.B. \&Nurick, A.J. (1993). The stages of team venture formation: A decision-making model. Entrepreneurship Theory and Practice, 17(2), 17-27.

129.Kolvereid, L. \&Bullvag, E. (1993). Novices versus experienced founders: An exploratory investigation. In S.

130.Birley, I. MacMillan, \& S. Subramony (Eds.), Entrepreneurship research: Global perspectives (pp. 275-285). Amsterdam, the Netherlands: Elsevier.

131.Lewicki, R.J. \& Bunker, B. (1996). Developing and maintaining trust in work relationships. In R.K.T. Tyler (Ed.), Trust in organizations (pp. 114-139). Newbury Park, CA: Sage.

132.MacMillan, I. (1986). To really learn about entrepreneurship, let's study habitual entrepreneurship. Journal of Business Venturing, 1, 241-243.

133.Mayer, R.C., Davis, J.H., \&Schoorman, F.D. (1995). An integrative model of organizational trust. Academy of Management Review, 20(3), 709-734.

134.Nordqvist, M. \& Zellweger, T. (2010). Transgenerational entrepreneurship. Cheltenham, U.K.: Edward Elgar.

135.Pearson, A.W., Carr, J.C., \& Shaw, J.C. (2008). Toward a theory of familiness: A social capital perspective. Entrepreneurship Theory and Practice, 32(6), 949-969.

136.Rosa, P. (1998). Entrepreneurial processes of business cluster formation and growth by "habitual" entrepreneurs. Entrepreneurship Theory and Practice, 22(4), 43-61.

137.Ruef, M., Aldrich, H., \& Carter, N. (2003). The structure of founding teams: Homophily, strong ties, and isolation among U.S. entrepreneurs. American Sociological Review, 68(2), 195-222.

138.Schulze, W., Lubatkin, M., \& Dino, R. (2003). Exploring the agency consequences of ownership dispersion among the directors of private family firms. Administrative Science Quarterly, 46(2), 179-194.

139.Schulze, W.S. \&Gedajlovic, E.R. (2010). Whither family business? Journal of Management Studies, 47(2), 191-204.

140.Ucbasaran, D., Lockett, A., Wright, M., \& Westhead, P. (2003). Entrepreneurial founder teams: Factors associated with member entry and exit. Entrepreneurship Theory and Practice, 28(2), 107-127.

141.Westhead, P. \&Howorth, C. (2007). "Types" of private family firms: An exploratory conceptual and empirical analysis. Entrepreneurship and Regional Development, 19(5), 405-431.

142.Westhead, P. \& Wright, M. (1998). Novice, portfolio and serial founders: Are they different? Journal of Business Venturing, 13(3), 173-204.

143.Wright, M. \&Vanaelst, I. (2009). Introduction. In M. Wright \& I. Vanaelst (Eds.), Entrepreneurial teams and new business creation (Vol. 13, pp. iix-xli). Cheltenham, U.K.: Edward Elgar. 